\title{
Can Change of Landscape Composition Increase Interspecies Competition Among Amphibians and Thus Decrease the Body Condition of the Endangered Bombina variegata?
}

\author{
Peter Mikolášs ${ }^{1,2 *}$ \\ ${ }^{1}$ Institute of High Mountain Biology, University of Žilina, \\ SK - 05956 Tatranská Javorina 7, Slovak Republic \\ ${ }^{2}$ Department of Ecology and Environmental Sciences, Faculty of Science, Palacký University, \\ Šlechtitelů 11 Olomouc, Czech Republic
}

Received: 18 March 2016

Accepted: 22 April 2016

\begin{abstract}
This study investigates the effect of forest cover in close proximity to breeding ponds $(\mathrm{N}=29)$ together with the effect of the presence or absence of other amphibian species on the residual body condition index of Bombina variegata $(\mathrm{N}=106)$. PCA and ANOVA analysis showed that body condition index was higher in toads found in breeding ponds with higher forest cover within a radius of $50 \mathrm{~m}$. This observation confirms the results of other authors. Other amphibian species (Bufo bufo, Rana temporaria, Triturus montadoni) occurred together with Bombina variegata mostly in ponds surrounded by larger deforested areas. Furthermore, the significantly lower body condition index of Bombina variegata was observed mostly in ponds occupied by other amphibian species $(\mathrm{p}<0.001)$. Results suggest that Bombina variegata is better adapted to shaded environments in comparison to other amphibians and therefore is able to achieve higher body condition in forest ponds not only due to higher nutrient availability and higher moisture but also decreased competition.
\end{abstract}

Keywords: deforestation, protected areas, land use, body condition index

\section{Introduction}

Bombina variegata is frequently described as a species that prefers open unshaded ponds. However, it is known that it can also flourish in cooler environments at higher altitudes [1]. According to Zavadil [2],this species is at present more common in forest environments because there are more permanent ponds and the microclimate

*e-mail: peter.mikolas44@gmail.com contains more moisture. Scheele [3] measured a higher body condition index of $B$. variegata in forest ponds, indicating adequate conditions in forests. However, at present deforestation is one of the main causes of amphibian decline [4-5].

Deforestation is not only a problem for amphibians in protected areas of Slovakia [6-7] but is also a global issue [8-10]. The main drivers of forest degradation in Slovakia are logging (both legal and illegal) [11] and construction of forest roads [12]. The change of microclimate and reduced 
food accessibility are just a few examples of what impacts amphibian physiology [13]. The abundance of predators and pathogens can also be significantly influenced by changes in habitat [14].

How changes in land-use patterns affect the distribution and abundance of organisms is an important question in ecology [15]. There is a great need to focus on individual processes that reflect proximal ecological mechanisms underlying population responses to landscape alterations [16-17]. In general, there are amphibian species that prefer open-canopy ponds and species that are adapted to cooler forest environments $[2,18]$. Several studies note a general pattern of increased species richness with increasing forest cover [19-21]. Forest environments provide advantages such as increased moisture and more nutrients.

On the other hand, ecological conditions of closedcanopy ponds may not be suitable for most amphibians. The effect of closed-canopy ponds on the distribution of amphibians was observed, for example, by Werner and Glennemeier [22], who found that either differences in resources or interactions between resources and low dissolved oxygen are largely responsible for the exclusion of some species from closed-canopy ponds. This type of pond was inimical, for example, to Rana sphenocephala and Anaxyrus americanus. The advantage of closedcanopy ponds is that they likely provide primarily detritusbased resources - especially bacteria and fungi associated with leaf decomposition [23].

The present study focused on the residual body condition index of $B$. variegata in relation to forest cover in close proximity to ponds and to the presence/ absence of other amphibian species. It was hypothesized that the body condition index of $B$. variegata would be lower in populations from ponds with largely deforested surroundings because ecological conditions are in such cases degraded by decreased humidity, decreased food availability, and increased stress due to logging and wood transportation, etc. It was also predicted that the body condition index of $B$. variegata would be lower in ponds colonized by other amphibians due to increased competition for resources. Monitoring the body condition index in amphibians is important for early management before extinction and for ensuring adequate protection of endangered species.

\section{Material and Methods}

\section{Study Area}

The study area is a part of the Bukovské Mountains, consisting mainly of coarse sandy flysch, greenish-grey and red claystone, and fine sandstone. The area belongs to a moderately warm region, with less than 50 summer days annually on average, and daily maximum air temperature $\geq 25^{\circ} \mathrm{C}$ and a July mean temperature of $16^{\circ} \mathrm{C}$.

Vegetation of the studied area is covered mostly by beech forests with such species as coralworts (Dentaria bulbifera, D. glandulosa), purple rattlesnake root
(Prenanthes purpurea), wood barley (Hordelymus europaeus), mountain fescue (Festuca drymeia), and wood speedwell (Veronica montana). Fir (Abies alba) occurs at higher locations with increased moisture. Deciduous trees such as Scotch elm (Ulmus montana), ash (Fraxinus excelsior), sycamore (Acer pseudoplatanus), and lime (Tillia cordata) can be found on sites with more humus and on talus. In these habitats the herb layer is also different, dominated by perennial honesty (Lunaria rediviva), dog's mercury (Mercurialis perennis), and white butterbur (Petasites albus). Maple-beech forests occur at the highest elevations (1,000-1,190 m.a.s.1.). Mountain brooks are lined by various willows (Salix aurita, S.silesiaca), butterburs (Petasites hybridus, P.kablikianus), pendulous sedge (Carex pendula), and shiny chervil (Anthriscus nitida) in the herb layer [12].

\section{Data Collection}

One-hundred and six samples of B. variegata from 29 localities were collected (Figs 1-2) in Poloniny National Park (Bukovske Mts.) between April and June 2013. Mass was measured to $0.5 \mathrm{~g}$ using PESOLA (50 g) and body length (snout to vent) to $0.02 \mathrm{~mm}$ by vernier calliper. Individuals with a snout-vent length greater than $30 \mathrm{~mm}$ were considered adults [24]. Environmental data were collected directly in the field: pond depth, elevation, and GPS coordinates (GARMIN Oregon 300 with precision $+/-7 \mathrm{~m}$ ) and the presence/absence of other amphibian species (Bufo bufo, Rana temporaria, Triturus montadoni). After log transformation of weight and body length measurements, the residual body condition index was calculated using SATISTICA 8.0 software (StatSoft, USA) according to Băncilă [25]. To investigate the effects of forest cover in close proximity to the breeding ponds of $B$. variegata on the body condition index, the surface of the deforested area was calculated around each of the locations within the circle with a radius of $50 \mathrm{~m}$. To perform these calculations ARC GIS software (version 10.2) was used with satellite imagery (DIGITAL

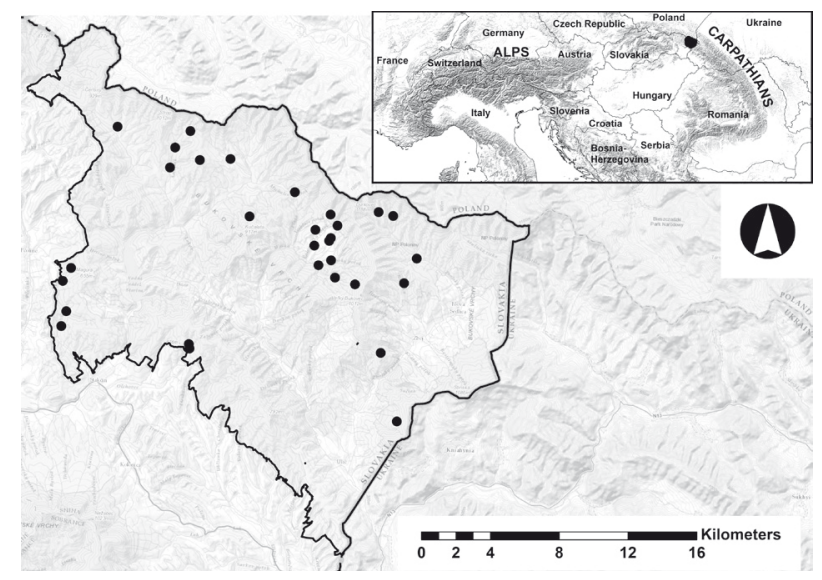

Fig. 1. Studied locations with the presence of $B$. variegata in Poloniny NP (Slovakia, N 4902'07.90"; E 22¹9'39.62"). 

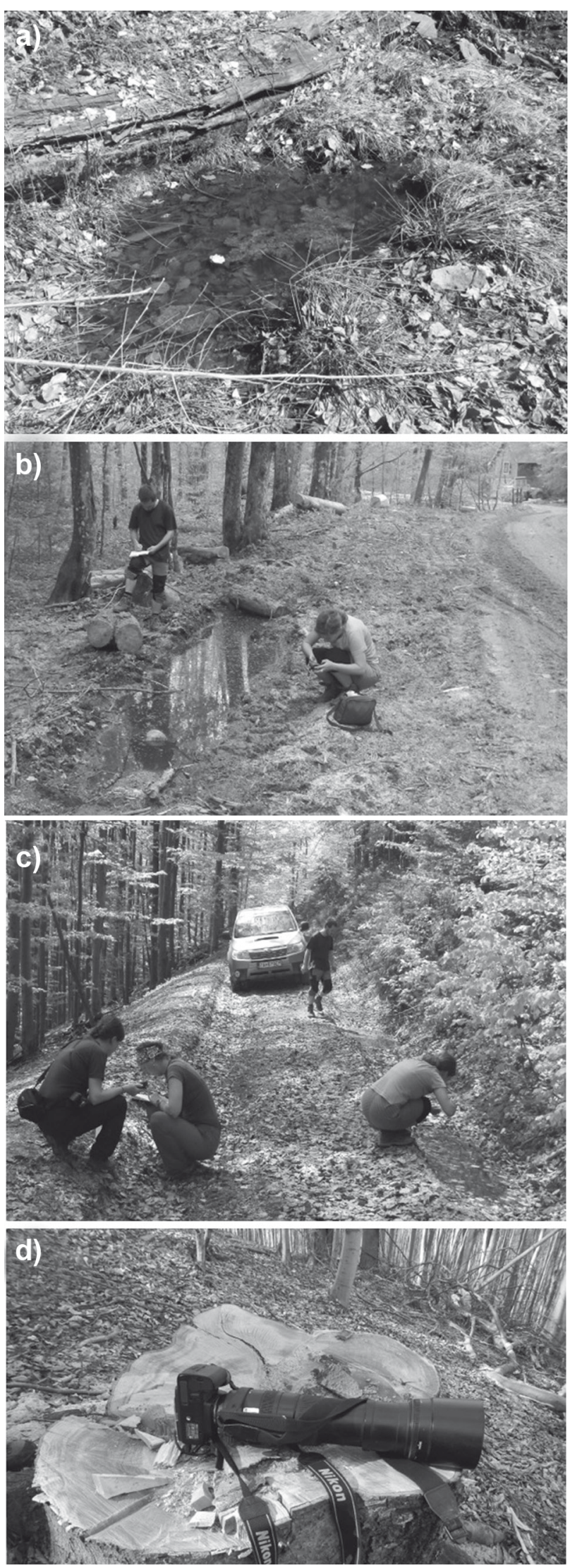

Fig. 2. Field data collection in Poloniny NP. a) Open-canopy pond with presence of $\mathrm{B}$. variegata together with egg clutches of R. temporaria. b) Closed-canopy pond with presence of only B.variegata. c) Breeding pond of B. variegata surrounded by deforested area due to forest road. d) Sign of logging activities in protected area near breeding ponds of $\mathrm{B}$. variegata.
GLOBE 25.8.2011) of the studied area, captured from Google Earth (Google, Inc. Mountain View, CA, USA) as a base-map.

\section{Statistical Analysis}

Statistical analyses were performed using Statistica 8.0 software (StatSoft, USA). Data were previously logtransformed. Principal component analysis (PCA) was used for evaluating the measurements. The variables used in PCA analysis were: residual body condition index, deforested area within $50 \mathrm{~m}$ of pond, elevation, pond depth. Principal components with an Eigen value greater than 1.0 were tested with ANOVA to reveal the effect of the presence or absence of other amphibians.

\section{Results and Discussion}

PCA results show that $B$. variegata had higher values of residual body condition index in deeper breeding habitats surrounded by larger areas of forest within 50 $\mathrm{m}$ and at lower elevations (Table 1). This is in agreement with Scheele [3], who found a higher body condition index among toads from forested landscapes compared to those from pasture ponds. According to Janin [26], body condition can be influenced by short- and longterm environmental stress. Body condition of Ensatina eschscholtzii was found to be significantly lower in thinned forests in Northwestern California [27]. Janin [26] detected poorer condition and elevated basal corticosterone levels in common toads found in landscapes characterized by both low forest availability and high forest fragmentation within a $500 \mathrm{~m}$ radius of ponds.

On the other hand, the results of the present study are in contrast with studies that describe $B$. variegata as a species preferring open pasture ponds [28-29]. Barandun and Reyer [28] found that B. variegata did not use cool or shaded as well as permanent ponds for spawning. Unshaded water bodies are also preferred by $B$. variegata pachypus [30]. So why can B. variegata be found in forested landscape with a higher body condition index? Zavadil [2] explained that in recent landscape types in

Table 1. Results of PCA analysis of selected variables.

\begin{tabular}{|c|c|c|c|}
\hline Variable & $\begin{array}{c}\text { PC Body } \\
\text { condition } \\
\text { index }\end{array}$ & $\begin{array}{c}\text { PC } \\
\text { Deforested } \\
\text { area }\end{array}$ & $\begin{array}{c}\text { PC Pond } \\
\text { depth }\end{array}$ \\
\hline $\begin{array}{c}\text { Residual body } \\
\text { condition index }\end{array}$ & 0.64 & -0.29 & 0.55 \\
\hline $\begin{array}{c}\text { Deforested area } \\
(\mathrm{r}=50 \mathrm{~m})\end{array}$ & -0.52 & 0.65 & 0.26 \\
\hline Elevation & -0.5 & -0.65 & -0.33 \\
\hline Pond depth & 0.57 & 0.34 & -0.67 \\
\hline Eigenvalue & 1.25 & 1.04 & 0.92 \\
\hline \% Total variance & 31.23 & 26.12 & 23.07 \\
\hline
\end{tabular}


Europe $B$. variegata has neither adequate aquatic nor terrestrial habitats outside the forest. If there is sufficient habitat outside the forest, toads prefer it.

Results of ANOVA (Fig. 3.) showed that ponds with less forest cover in their surroundings and at lower elevations were inhabited by other amphibians besides $B$. variegata, likely due to increased temperature of breeding habitats. Environmental temperature is positively correlated with rate of growth and metamorphosis [3132]. Shallow, warm, and productive ponds allow faster larval development and rapid attainment of developmental threshold [33-34]. Other species found in ponds with $B$. variegata were B. bufo, $R$. temporaria, and T. montadoni - all of which can also be found in forest landscapes [2].
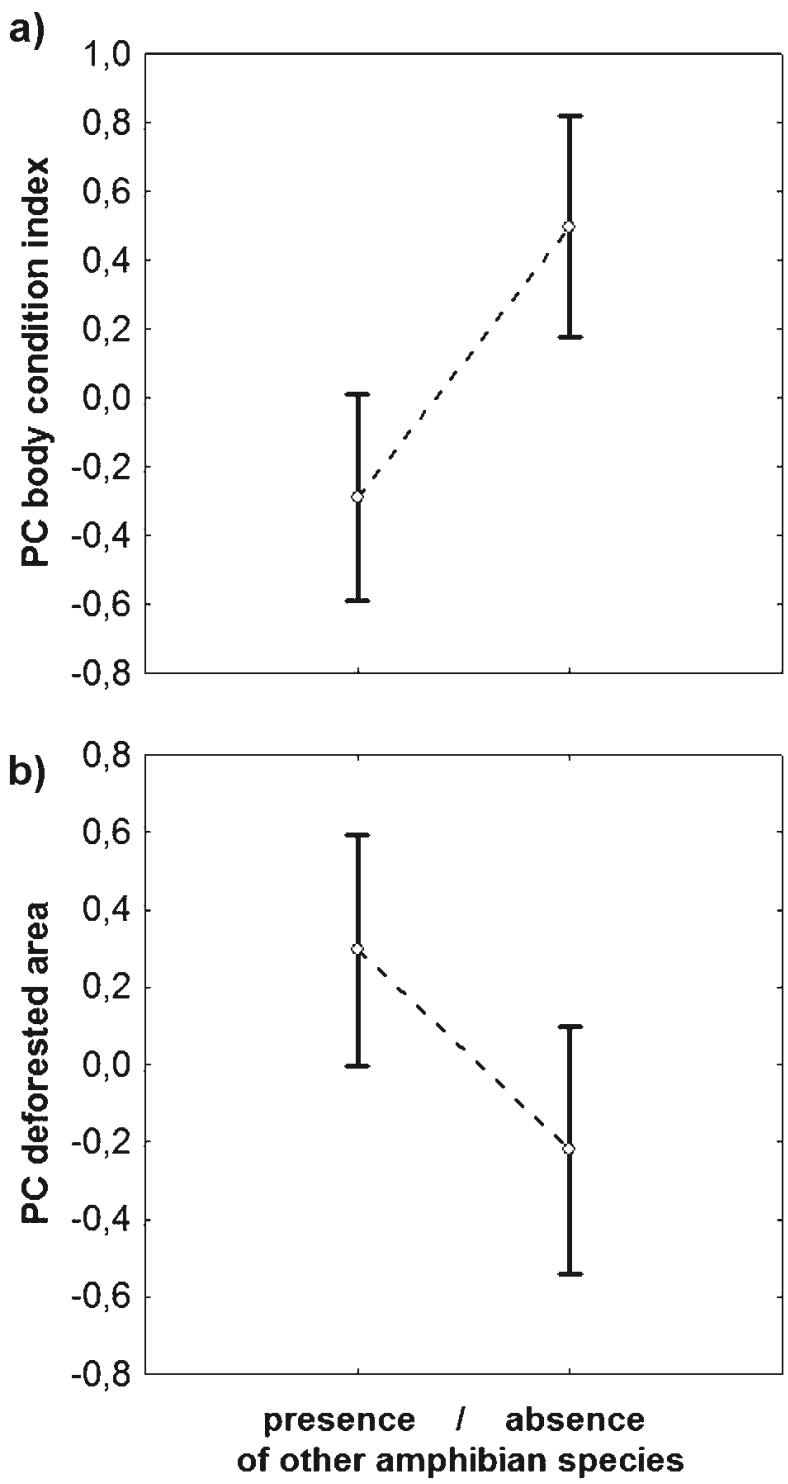

Fig. 3. Comparison of principal components given in Table 1 with Eigen values $>1$ using ANOVA $+/$ - standard deviation. a) Body condition index of $B$. variegata was significantly lower in ponds with presence of other amphibian species ( $F$ $(1,104)=12.541, \mathrm{p}<0.001)$. b) Deforested area was significantly larger around ponds with presence of other amphibian species including $B$. variegata $(\mathrm{F}(1,104)=5.48, \mathrm{p}<0.05)$.
Hartel [35] observed that ponds preferred by B. variegata for reproduction also contained predatory newts (Triturus vulgaris, Triturus cristatus) and insects (Odonata, Dytiscidae).

ANOVA analysis (Fig. 3) also shows that B. variegata had a higher body condition index in ponds situated in forest and without the presence of other amphibians. It is clear that B. variegata, like many other amphibians, prefers warmer ponds outside the forest, but its body condition index can be reduced by competition pressure from other species occupying the same ponds. It is possible that the absence of other amphibians in forest ponds is one of the reasons for a higher body condition index of $B$. variegata, in addition to higher resource availability, more humid micro-climatic conditions, and higher water availability. On the other hand in the case of intraspecific competition Scheele [3] observed no correlation between body condition index and the relative abundance of $B$. variegata. This can be explained by the tendency of toads to frequently move between ponds in a radius of up to 200 $\mathrm{m}$ [36]. The more ponds the toad uses, the more resources are available. Therefore, the body condition of adults may not be affected by intraspecific competition if ponds are occupied by $B$. variegata only. However, competition of $B$. variegata conspecifics was observed as a stress factor during their larvae stadium. For example, experimental studies made by Hartel [35] indicated that larval mortality was high in crowded conditions. Jasieński [37] compared the growth and development of sibling and non-sibling $B$. variegata larvae under high-density conditions and found a negative effect of the larger non-sibling tadpoles.

The present study emphasizes that forest is a very important habitat for the internationally endangered $B$. variegata (European Union Habitats Directive Annex II and IV) because it may serve as a refugium with lower competition pressure in contrast to open habitats. The forest also provides better conditions in times of drought [2-3]. Therefore, deforestation may be a serious threat to $B$. variegata in recent and future rural landscapes. While some disturbance of landscape can increase amphibian diversity by creating new breeding habitats [30], on the other hand deforestation can reduce fitness of individuals due to reduction of resources, etc. [3].

There is a need for long-term studies to assess the abundance of all amphibian species occupying the same ponds and to investigate how this affects their body condition index. A long-term study assessing the body condition index of toads would also reveal the trend in their fitness and provide a warning in case of decreasing trends.

\section{Conclusions}

This study found that body condition index of $B$. variegata was higher in breeding ponds surrounded by forest landscape in Poloniny National Park (Bukovske Mountains, Slovakia) in comparison to ponds situated in deforested areas. This trend is in agreement with other 
investigations conducted in other parts of Europe [3], which emphasizes that forest habitats are important for the protection of internationally endangered amphibian species. Results also showed that amphibian diversity of breeding ponds situated in a deforested landscape is higher (B. variegata, B. bufo, R. temporaria, T. montadoni), but the body condition index of $B$. variegata was in these ponds lower in contrast to locations situated in a forest landscape, where the amphibian diversity was smaller and often occupied only by $B$. variegata. These observations suggest that deforestation around amphibian breeding ponds can cause changes in species composition and thus increase interspecies competition, leading to a decrease of amphibian body condition index.

\section{Acknowledgements}

This study was partly supported by a project of the Swiss Contribution and State Nature Conservancy of Slovakia [1551/2011], titled "Development of nature protection and protected areas in the Slovakian Carpathians," and partly by Structural Funds of an EU project of the Agency of the Ministry of Education, Science, Research, and Sport of the Slovak Republic, Bratislava (ITMS No. 26110230078). The Institute of High Mountain Biology was permitted (No. 4797/2008-2.1) to catch and examine protected species in accordance with Act No. 543/2002 on nature and landscape protection. My sincere thanks to Marián Janiga, Zuzana Hrehová, Tomáš Vatycha, Jaroslav Stoklasa, Edita Karaščáková, Monika Pajonková, Ján Graban, and Natália Maximová for their valued assistance in the field. I also thank Robin Rigg of the Slovak Wildlife Society for linguistic assistance.

\section{References}

1. CICORT-LUCACIU A.S., CUPSA D., ILIES D., ILIES A., BAIAS S., SAS I. Feeding of two amphibian species (Bombina variegata and Pelophylax ridibundus) from artificial habitats from Pădurea Craiului Mountains (Romania). North-West J. Zool, 7, 297, 2011.

2. ZAVADIL V., SÁDLO J., VOJAR, J. Biotopy našich obojživelníků a jejich management. [Habitats of Czech Amphibians and their Management]. AOPK ČR, Prague, pp. 178, 2011 [In Czech].

3. SCHEELE B.C., BOYD C.E., FISCHER J., FLETCHER A.W., HANSPACH J., HARTEL T. Identifying core habitat before it's too late: the case of Bombina variegata, an internationally endangered amphibian. Biodivers. Conserv., 23, 775, 2014.

4. BECKER C.G., RODRIGUEZ D., LONGO A.V., TOLEDO L.F., LAMBERTINI C., LEITE D. S., HADDAD C.F.B., ZAMUDIO K. R. Deforestation, host community structure, and amphibian disease risk. Basic Appl. Ecol. 17, 72, 2016.

5. KONOPIK O., STEFFAN-DEWENTER I., GRAFE T.U. Effects of Logging and Oil Palm Expansion on Stream Frog Communities on Borneo, Southeast Asia. Biotropica, 47, 636, 2015.

6. SOLÁR J., JANIGA M., MARKULJAKOVÁ K. The Socioeconomic and Environmental Effects of Sustainable
Development in the Eastern Carpathians, and Protecting its Environment. Pol. J. Environ. Stud., 25, 291, 2016.

7. KOPECKA M. 2011. Destruction of the forest habitat in the Tatra National Park, Slovakia. In: GRILLO O., GIANFRANCO V. (Eds.) Biodiversity Loss in a Changing Planet, InTech Open, Rijeka, 257, 2011.

8. DI MARCO M., BUTCHART S.H., VISCONTI P., BUCHANAN G.M., FICETOLA G.F., RONDININI C. Synergies and trade-offs in achieving global biodiversity targets. Conserv. Biol., 30, 189, 2016.

9. SPRACKLEN B.D., KALAMANDEEN M., GALBRAITH D., GLOOR E., SPRACKLEN D.V.A. Global Analysis of Deforestation in Moist Tropical Forest Protected Areas. PloS one, 10, 2015.

10. SALVATI L., BIASI R., CARLUCCI M., FERRARA A. Forest transition and urban growth: exploring latent dynamics (1936-2006) in Rome, Italy, using a geographically weighted regression and implications for coastal forest conservation. Rendiconti Lincei, 26, 577, 2015.

11. BOURIAUD L. Causes of illegal logging in Central and Eastern Europe. Small-scale For. Econ. Manage. Policy, 4, 269, 2005.

12. JASÍK M., POLÁK P., (eds.) Pralesy Slovenska [Primeval forests in Slovakia], FSC Slovensko: Banská Bystrica, pp. 228, 2011 [In Slovak].

13. MATÍAS-FERRER N., ESCALANTE P. Size, body condition, and limb asymmetry in two hylid frogs at different habitat disturbance levels in Veracruz, Mexico. Herpetol J., 25, 176, 2015.

14. LIPS K.R. Mass mortality and population declines of anurans at an upland site in western Panama. Conserv. Biol., 13, 117, 1999.

15. FICETOLA G.F., MAIORANO L., FALCUCCI A., DENDONCKER N., BOITANI L., PADOA-SCHIOPPA E., MIAUD C., THUILLER W. Knowing the past to predict the future: land-use change and the distribution of invasive bullfrogs. Glob. Change Biol., 16, 528, 2010.

16. BRUM F.T., GONÇALVES L.O., CAPPELATTI L., CARLUCCI M. B., DEBASTIANI V.J., SALENGUE E. V., DOS SANTOS SEGER G.D., BOTH C., BERNARDOSILVA J.S., LOYOLA R.D., DA SILVA DUARTE L. Land use explains the distribution of threatened new world amphibians better than climate. PloS one, 8, 2013.

17. HOF C., ARAÚJO M.B., JETZ W., RAHBEK C. Additive threats from pathogens, climate and land-use change for global amphibian diversity. Nature, 480, 516, 2011.

18. WELLS K.D. The ecology and behavior of amphibians. University of Chicago Press, 1400, 2010.

19. FELTON A., KNIGHT E., WOOD J., ZAMMIT C., LINDENMAYER D. A meta-analysis of fauna and flora species richness and abundance in plantations and pasture lands. Biol. Conserv., 143, 545, 2010.

20. KOLOZSVARY M.B., SWIHART R.K. Habitat fragmentation and the distribution of amphibians, patch and landscape correlates in farmland. Can. J. Zool., 77, 1288, 1999.

21. HOULAHAN J.E., FINDLAY C.S., SCHMIDT B.R., MEYER A.H., KUZMIN S.L. Quantitative evidence for global amphibian population declines. Nature 404, 752, 2000.

22. WERNER E.E., GLENNEMEIER K.S. Influence of forest canopy cover on the breeding pond distributions of several amphibian species. Copeia, 1, 1, 1999.

23. WEBSTER J.R., BENFIELD E.F. Vascular plant breakdown in freshwater ecosystems. Annu. Rev. Ecol. Syst., 17, 567, 1986. 
24. DI CERBO A.R., BIANCARDI C.M. Are there real sexual morphometric differences in yellow-bellied toads (Bombina spp.; Bombinatoridae)? Amphibia-Reptilia, 33, 171, 2012.

25. BĂNCILĂ R.I., HARTEL T., PLĂIAŞU R., SMETS J., COGĂLNICEANU D. Comparing three body condition indices in amphibians: a case study of yellow-bellied toad Bombina variegata. Amphibia-Reptilia, 31, 558, 2010.

26. JANIN A., LÉNA J.P., JOLY P. Beyond occurrence: body condition and stress hormone as integrative indicators of habitat availability and fragmentation in the common toad. Biol. Conserv., 144, 1008, 2011.

27. KARRAKER N.E., WELSH H.H. Long-term impacts of even-aged timber management on abundance and body condition of terrestrial amphibians in Northwestern California. Biol. Conserv., 131, 132, 2006.

28. BARANDUN J., REYER H.U. Reproductive ecology of Bombina variegata: characterisation of spawning ponds. Amphibia-Reptilia, 18,143, 1997.

29. HARTEL T., SZILÁRD N., MARA G. Breeding phenology and spatio-temporal dynamics of pond use by the yellowbellied toad (Bombina variegata) population: the importance of pond availability and duration. Acta Zool. Lit., 17, 56, 2007.

30. CANESSA S., ONETO F., OTTONELLO D., ARILLO A., SALVIDIO S. Land abandonment may reduce disturbance and affect the breeding sites of an endangered amphibian in northern Italy. Oryx, 47, 280, 2013.
31. NEWMAN R.A. Effects of changing density and food level on metamorphosis of a desert amphibian, Scaphiopus couchii. Ecology, 75, 1085, 1994.

32. WHEELER C.A., BETTASO J.B., ASHTON D.T., WELSH JR. H.H. Effects of Water Temperature on Breeding Phenology, Growth, and Metamorphosis of Foothill YellowLegged Frogs (Rana boylii): A Case Study of the Regulated Mainstem and Unregulated Tributaries of California's Trinity River. River Res. Appl., 31, 1276, 2015.

33. NORLIN L., BYSTRÖM P., KARLSSON J., JOHANSSON M., LIESS A. Climate change will alter amphibian-mediated nutrient pathways: evidence from Rana temporaria tadpoles in experimental ponds. Freshwater Biol., 61, 472, 2016.

34. RICHTER-BOIX A., KATZENBERGER M., DUARTE H., QUINTELAM., TEJEDOM.,LAURILAA.Local divergence of thermal reaction norms among amphibian populations is affected by pond temperature variation. Evolution 69, 2210 . 2015.

35. HARTEL T. An experimental study on the abundance effect on tadpole growth, mortality and metamorphosis in Bombina variegata. Biota 6, 27, 2007.

36. HARTEL T. Movement activity in a Bombina variegata population from a deciduous forested landscape. North-West J. Zool., 4, 79, 2008.

37. JASIEŃSKI M. Kinship ecology of competition - size hierarchies in kin and nonkin laboratory cohorts of tadpoles. Oecologia 77, 407, 1988. 